\title{
Antioxidant activity from the leaf extracts of Jacaranda puberula Cham., Bignoniaceae, a Brazilian medicinal plant used for blood depuration
}

\author{
Paula Macedo Lessa dos Santos, ${ }^{* 1}$ Alberto Sadda Japp, ${ }^{2}$ Lívia Gralato Lima, ${ }^{2}$ \\ Jan Schripsema, ${ }^{3}$ Fábio de Sousa Menezes, ${ }^{4}$ Ricardo Machado Kuster ${ }^{2}$
}

\author{
${ }^{1}$ Instituto de Química, Centro de Tecnologia, Laboratório PXQMed, Polo de Xistoquímica, Universidade Federal \\ do Rio de Janeiro, Ilha do Fundão, 21941-614 Rio de Janeiro-RJ, Brazil \\ ${ }^{2}$ Núcleo de Pesquisas de Produtos Naturais, Centro de Ciências da Saúde, Bloco H, Universidade Federal do \\ Rio de Janeiro, Ilha do Fundão, 21941-590 Rio de Janeiro-RJ, Brazil \\ ${ }^{3}$ Grupo Metabolomica, Laboratório de Ciências Químicas, Centro de Ciências e Tecnologia, Universidade Estadual \\ do Norte Fluminense, Av. Alberto Lamego, 2000, 28013-602 Campos dos Goytacazes-RJ, Brazil \\ ${ }^{4}$ School of Pharmacy and Pharmaceutical Sciences, Trinity College Dublin, University of Dublin, \\ 23 Westland Row, Dublin 2, Ireland.
}

\begin{abstract}
RESUMO: “Atividade antioxidante do extrato das folhas de Jacaranda puberula Cham., Bignoniaceae, uma planta medicinal brasileira usada como depurativo do sangue”. Os extratos obtidos a partir das folhas de Jacaranda puberula Cham., Bignoniaceae, foram avaliados quanto à atividade antioxidante utilizando-se o método do radical livre DPPH (2,2-difenil-1-picrilhidrazila). Também foram incluídos na avaliação três medicamentos fitoterápicos comerciais ( $\mathrm{F} 1$, F2 e F3) indicados como depurativos do sangue. Através da descoloração das soluções testadas, foi possível medir o potencial sequestrador do radical DPPH. Como referência, utilizou-se os dados da literatura de $\mathrm{CE}_{50}$ do extrato padronizado de Gingko biloba EGb $761^{\circledR}$ e o flavonoide rutina, ambos empregados em medicamentos com atividade antioxidante. Entre os extratos testados, os que apresentaram valores baixos de $\mathrm{CE}_{50}$ foram os extratos etanólico bruto (EE), em acetato de etila (EA), em butanol (EB), aquoso (EAq) e da amostra A, obtida do extrato EB. Os fitoterápicos comerciais apresentaram altos valores de $\mathrm{CE}_{50}$. Com base nos resultados das análises feitas por de RMN de ${ }^{13} \mathrm{C}$ e ${ }^{1} \mathrm{H}$, CLAE-DAD e de acordo com os dados da literatura, a presença de substâncias fenólicas como o verbascosídeo (1) e o aldeído cis-caféico (2), contribuíram para a atividade antioxidante (AA) dos extratos ativos.
\end{abstract}

Unitermos: Jacaranda puberula, Bignoniaceae, depurativo, atividade antioxidante, verbascosídeo, aldeído cis-caféico.

\begin{abstract}
The antioxidant activity of leaf extracts from Jacaranda puberula Cham., Bignoniaceae, was assayed by the DPPH (2,2-diphenyl-1-picryl-hydrazyl) free radical scavenging method. Three phytomedicines (F1, F2, and F3) used as blood depurative, were tested by the same method. The free radical scavenger potential was measured by the discoloration of the solution. The $\mathrm{EC}_{50}$ values from Gingko biloba EGb $761^{\circledR}$ extract and rutin, used as antioxidant for medical purposes, were used as reference. The ethanol extract (EE), ethyl acetate (EA), butanol (EB), aqueous (EAq) and the sample A (obtained from extract $\mathrm{EB}$ ), showed lower $\mathrm{EC}_{50}$ values than other extracts and phytomedicines. The antioxidant activity (AA) of the extracts was related with the presence of the polyphenol compounds such as verbascoside (1) and cis-caffeoyl aldehyde (2). These structures were determined by chemical and spectroscopic methods and comparison with literature data.
\end{abstract}

Keywords: Jacaranda puberula, Bignoniaceae, depurative, antioxidant activity, verbascoside, ciscaffeoyl aldehyde. 


\section{INTRODUCTION}

Jacaranda puberula Cham., Bignoniaceae, is a plant specie from the Brazilian Atlantic forest (Lorenzi, 2002) and is known in Brazil as carobinha and it is used in folk medicine for blood depuration (Corrêa, 1975; Martins et al., 2008). The tea is prepared from leaves decoction and used as a depurative drink.

Medical literature reports the beneficial action of antioxidants agents in the prevention of several diseases, which are presumed to be caused by or related to the excess of free radicals in the human organism such as cancer, arterial hypertension, heart diseases and diabetes among others. Excess of free radicals production at the blood plasma leads to the lipid hyperoxidation that has direct relation with the atheroma formation and atheriosclerosis (Valko et al., 2007)

The popular use of Jacaranda puberula as depurative, led us to explore this concept through the possible correlation between the blood purification effect and the antioxidant potential of the leaf extracts. Also some common phytomedicinal drugs used for body depuration were investigated. The present study evaluated the antioxidant activity of the dry extracts of $J$. puberula and the sample A obtained from the purification of butanol extract (EB). According to the label, the phytomedicines F1, F2 and F3 contained several plant extracts, infuses and tinctures on their formulations (Chart 1 for plant constituents).

Chart 1. Vegetal composition of the phytomedicines evaluated at the antioxidant assay.

\begin{tabular}{cl}
\hline Medicine & \multicolumn{1}{c}{ Vegetal composition } \\
\hline F1 & Extracts: caroba (Jacaranda caroba), \\
& carqueja (Bacharis genistelloides), chapéu \\
& de couro (Echinodorus macrophylus), cipó \\
& cravo (Tynnanthus fasciculatus), cipó suma \\
& (Anchieta salutaris), salsaparrilha (Smilax \\
& officinalis), sassafrás (Ocotea pretiosa), uva \\
& ursi (Arctostaphylos uva ursi) \\
F2 & Fluidextracts:inhame(Colocasiaantiquorum), \\
& salsaparrilha (Smilax papyracea) \\
& Tinctures: badiana (Illiicium verum), baunilha \\
& (Vanilla planifolia), samambaia (Polypodium \\
& lepidopteris), cipó suma (Anchietia salutaris), \\
& caroba(Jacaranda caroba), fumaria (Fumaria \\
& officinalis); fluid extracts: nogueira (Juglans \\
& regia), pé de perdiz (Croton perdiceps); syrup \\
& (peels): laranja (Citrus aurantium); Infuse: \\
& salsaparrilha (Smilax papyracea)
\end{tabular}

\section{MATERIAL AND METHODS}

\section{General}

The radical DPPH was purchased from Sigma.
The absorbance analysis were made in a UV-VIS Shimadzu 2200 spectrometer. All reagents were of analytical grade and obtained from Merck. The HPLC analysis were carried out on a Shimadzu SPD-M10A coupled to a Diode Array Detector (DAD), equipped with a LC-10AD bomb and a CBM-10A Detector. A RP-18 column, ODS $25 \mathrm{~cm}$ x 4.6 $\mathrm{mm} 5 \mu$, from the Rexchrom-Regis, was employed at room temperature. Solvents used were of HPLC grade from Tedia. The ${ }^{1} \mathrm{H}$ NMR and ${ }^{13} \mathrm{C}$ NMR spectra were obtained in $\mathrm{CD}_{3} \mathrm{OD}$ and DMSO-d $\mathrm{d}_{6}$ on a Varian Gemini 200, Jeol+400 or Bruker Avance 400 spectrometer. Chemical shifts are reported in ppm relative to TMS. The phytomedicines used in this study were purchased from drugstores in Rio de Janeiro city and neighborhood.

TLC was performed using silica gel (Merck 60 $\mathrm{F}_{254}$ ) with the eluents A (EtOAc:MeOH:H2O 8:1.5:0.5) or B (EtOAc:MeOH:H2O:Acetic acid 8:1.5:0.5:0.5). $\mathrm{NP} / \mathrm{PEG}$ was used as chromogenic reagent for all TLC analysis.

\section{Plant material}

Jacaranda puberula Cham., Bignoniaceae, was acquired at the municipal market in Duque de Caxias, Rio de Janeiro. A voucher sample is deposited at the herbarium of the Biology Institute of the Federal University of Rio de Janeiro (UFRJ) under number 103011.

\section{Sample preparation}

Air dried leaves (1.2 kg.) were grounded and extracted with $3 \mathrm{~L}$ of ethanol for two weeks. The EtOH extract was concentrated to dryness under reduced pressure yielding $112.4 \mathrm{~g}$ of crude ethanol extract (EE) that was suspended in ethanol: $\mathrm{H} 2 \mathrm{O}(9: 1)$ and partitioned with hexane to furnish $25.5 \mathrm{~g}$ of the hexane extract $(\mathrm{EH})$. Ethanol was evaporated from the solution and the aqueous suspension was partitioned with dichloromethane, ethyl acetate, and butanol successively to furnish the corresponding extracts at $12.5 \mathrm{~g}$ (ED), $18.2 \mathrm{~g}$ (EA) and $20.3 \mathrm{~g}$ (EB), remaining the aqueous extract (EAq).

\section{Sample A}

TheEB extract(1g)was subject to chromatography on a glass column, packed with Sephadex-LH 20, eluted with $\mathrm{MeOH}: \mathrm{H}_{2} \mathrm{O}$ 1:1 (fractions 01 to 61), and pure methanol (62 to 88). These fractions ( $30 \mathrm{~mL}$ each) were subject to TLC using eluent A for fractions 01 to 40 and eluent $\mathrm{B}$ for the fractions 23 to 88 . The main groups were named Bu-1 (10 and 11; $20 \mathrm{mg}), \mathrm{Bu}-2$ (18-21; $50 \mathrm{mg})$, Bu-3 (23 and 24; $13 \mathrm{mg}$ ) and Bu-4 (27-32; $30 \mathrm{mg})$.

The Sample Bu-2 (50 mg) was applied in a column of Sephadex-LH 20, eluted with pure $\mathrm{MeOH}$, yielding 24 fractions (10 mL each), subjected to TLC analyses in silica gel; eluted with eluent A (01 to 16) and eluent B (11 to 24). 
The fractions 16 to $24(30 \mathrm{mg})$ were gathered and named Sample A. The structure was elucidated by ${ }^{1} \mathrm{H}$ NMR and ${ }^{13} \mathrm{C}$ NMR analyses, utilizing $1 \mathrm{D}$ and 2D techniques, including HMQC and HMBC.

\section{Sample B}

The EA extract ( $3 \mathrm{~g})$ was applied on glass column packed with Sephadex-LH 20 eluted with $\mathrm{MeOH}: \mathrm{H}_{2} \mathrm{O}$ 1:1 (01 to 28), $\mathrm{MeOH}: \mathrm{H}_{2} \mathrm{O}$ 7:3 (29 to 38) and pure methanol (39 to 71). These fractions (30 mL each) were subjected to TLC with eluent A (01 to 26$)$ and eluent B (27 to 71$)$. The main groups obtained were named Ac-1 (12-16; 116.9 $\mathrm{mg})$, Ac-2 (17-25; $221 \mathrm{mg})$, Ac-3 (33-36; $145.7 \mathrm{mg})$, Ac-4 (37 and 38; $72.6 \mathrm{mg}$ ), Ac-5 (49 and 50; $20 \mathrm{mg}$ ) and Ac-6 (63-67; $6 \mathrm{mg})$.

The Sample Ac-3 (100 mg) was applied on a glass column packed with Sephadex-LH 20, eluted with pure $\mathrm{MeOH}$, yielding twelve fractions (10 $\mathrm{mL}$ each). The fractions were gathered after TLC in silica gel analyses; eluted with eluent A, obtaining the Sample Ac-37 (fraction 7; $41 \mathrm{mg}$ ).

The Sample Ac-37 (37 mg) was applied on a glass column packed with Sephadex-LH 20, eluted with pure $\mathrm{MeOH}$, yielding twenty fractions ( $3 \mathrm{~mL}$ each), gathered by TLC analysis in silica gel; eluted with eluent A, obtaining sample B (fractions 15 to $18 ; 20 \mathrm{mg}$ ). The structure was elucidated by ${ }^{1} \mathrm{H}$ NMR and ${ }^{13} \mathrm{C}$ NMR analyses, utilizing 1D and 2D techniques, including HMQC and HMBC.

\section{Preparation of the phytomedicines samples}

The phytomedicines (F1, F2 and F3) chosen for the antioxidant assay were concentrated under reduce pressure to remove the liquid vehicle (ethanol and/or water) for obtaining the dry material to be weighted for the preparation of the solutions. All the phytomedicines were acquired and tested inside the valid expiration date.

\section{HPLC-DAD analysis}

The samples were dissolved in methanol, to obtain a final concentration of $20 \mathrm{mg} / \mathrm{mL}$. The solutions of the extracts of EE, EH and ED were filtered through Millipore filter before analysis. EAq was solubilized in methanol added with seven drops of Mili-Q water. $20 \mu \mathrm{L}$ of each sample were injected per run, at system of $0,1 \%$ of phosphoric acid in water (solvent A) and pure methanol (solvent B), employing a gradient elution: 1-10 min 70\% of A, $20 \mathrm{~min} 60 \%$ of A, $60 \mathrm{~min} 100 \%$ of A and stop in the $61 \mathrm{~min}$. The ultraviolet detection was realized in $254 \mathrm{~nm}$ and in $278 \mathrm{~nm}$.

\section{Antioxidant activity assay}

The antioxidant activity of the samples was evaluated by the DPPH radical method described by Mensor et al. (2001).

\section{RESULTS AND DISCUSSION}

The results showed values of $\mathrm{EC}_{50}$ for the extracts and for the tested compounds against the stable DPPH free radical, which produced a violet solution in methanol in this oxidized form and by its discoloration when reduced by antioxidants molecules (Table 1 ). $\mathrm{EC}_{50}$ was defined as the amount of antioxidant necessary to decrease the initial DPPH radical concentration by $50 \%$ (Efficient Concentration $=\mathrm{EC}_{50}$ ) of a maximum effect estimate in $100 \%$. The explanation of that resides is in the fact that some polyphenol compounds like coumaric acid and vanillin don't react more than $75 \%$ with DPPH even in high concentrations and long time reactions, around $7 \mathrm{~h}$ (Williams et al., 1995).

Table 1. $\mathrm{EC}_{50}$ values of the extracts from Jacaranda puberula and phytomedicines F1, F2 and F3. Gingko biloba and rutin were used as standards.

\begin{tabular}{cc}
\hline Sample & $\mathrm{EC}_{50} \mu \mathrm{g} / \mathrm{mL}$ \\
\hline $\mathrm{EE}$ & 30.59 \\
$\mathrm{EH}$ & 7625.81 \\
$\mathrm{ED}$ & 79.18 \\
$\mathrm{EA}$ & 28.05 \\
$\mathrm{~EB}$ & 25.18 \\
$\mathrm{EAq}$ & 43.79 \\
$\mathrm{~F} 1$ & 7334891.75 \\
$\mathrm{~F} 2$ & 329457723.87 \\
$\mathrm{~F} 3$ & $4.33 \times 10^{40}$ \\
Ginkgo biloba (EGb 761 & 39 \\
$\mathrm{~A}$ (Verbascoside) extract & 12.57 \\
Rutin & 14.16 \\
\hline
\end{tabular}

Comparing the $\mathrm{EC}_{50}$ values obtained from Jacaranda puberula Cham., Bignoniaceae, extracts and phytomedicines F1, F2 and F3 with the Ginkgo biloba results (Mensor et al., 2001), it was observed that the extracts of EE $(30.59 \mu \mathrm{g} / \mathrm{mL})$, EB $(28.05 \mu \mathrm{g} / \mathrm{mL})$ and EA $(25.18 \mu \mathrm{g} / \mathrm{mL})$ showed a higher antioxidant activity $G$. biloba $\left(\mathrm{EGb} 761^{\circledR}\right)$ at $39 \mu \mathrm{g} / \mathrm{mL}$.

For EA and EB extracts, the reaction of discoloration of DPPH solution occurred in less than one minute. Phytomedicines F2 and F3 showed high values of $\mathrm{EC}_{50}$, but F1, containing J. caroba as one of the constituents, presented the lower value for antioxidant activity at $7.3 \mathrm{~g} /$ $\mathrm{mL}$. This is an interesting result since the recommended daily dose for $\mathrm{F} 1$ is $60 \mathrm{~mL}$, corresponding to $9.5 \mathrm{~g}$ of the product.

The extracts and the medicines with low antioxidant activity showed in the HPLC-DAD analyses low quantities or absence of compounds that could absorb 
in 254 and $278 \mathrm{~nm}$. These results suggested a relation between compounds with chromophores, such as phenol compounds, and antioxidant activity. The samples with higher antioxidant activity showed compounds with absorption at the UV in 254 and $278 \mathrm{~nm}$.

A compound with retention time at 23-24 min, with high relative concentration in the extracts EE, EA, EB and EAq (Figure 1), showed a spectrum of UV characteristic of a phenylpropanoid with higher absorption at $331 \mathrm{~nm}$ and a shoulder at $260 \mathrm{~nm}$ (Gafner et al., 1997).

Compared to the flavonoid rutin $\left(\mathrm{EC}_{50} 14.16 \mu \mathrm{g} /\right.$ $\mathrm{mL})$, Sample A showed a good antioxidant activity $\left(\mathrm{EC}_{50}\right.$ $12.57 \mu \mathrm{g} / \mathrm{mL}$ ). TLC analysis showed the presence of the same compound in Sample A, EE, ED, EB, EA and EAq, which under UV light after NP/PEG spraying, produced a yellow-green spot. The HPLC-DAD chromatogram of this compound showed a peak in $23.9 \mathrm{~min}$ and the UV absorption spectrum (Figure 2B) a maximum absorption in $331 \mathrm{~nm}$ with shoulder in $260 \mathrm{~nm}$, similar to the phenyl propanoid group.

This compound was isolated from the EB extract and through its NMR data (Table 2) and comparison with literature data (Castro et al., 1990; Gafner et al., 1997; Didry et al., 1999; Kanchanapoom et al., 2002) it was identified as the phenyl propanoid glycoside, 3,4dihydroxy- $\beta$-phenylethyl 1-O- $\alpha$-L-rhamnopyranosyl- $(1,3)$ 4-O-caffeoyl- $\beta$-D-glucopyranoside,verbascoside 1.
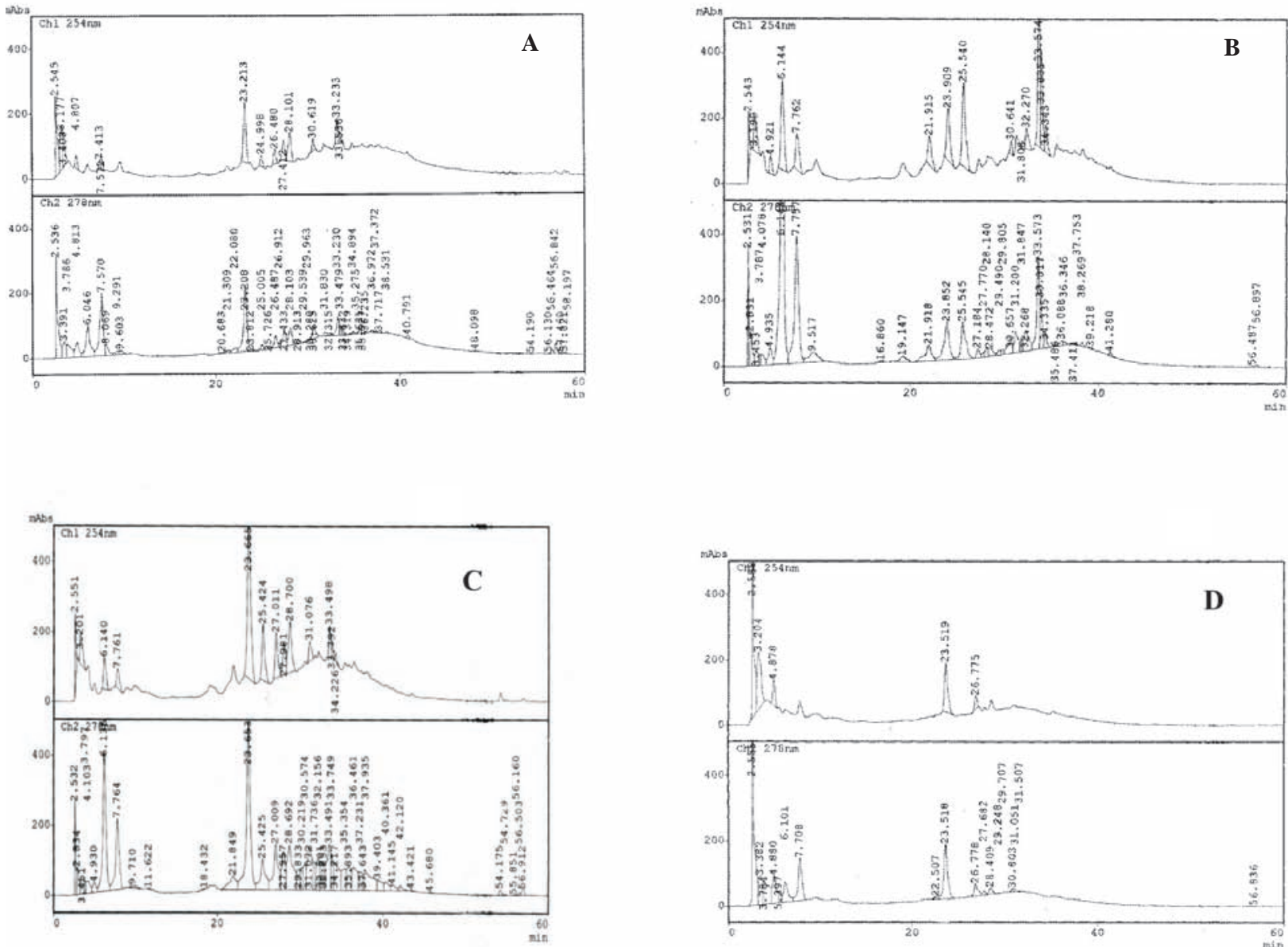

Figure 1. Chromatograms of HPLC-DAD from the following extracts EE (A), EA (B), EB (C) and EAq (D) of Jacaranda puberula, from the compounds with retention times around 6 and $23 \mathrm{~min}$. 

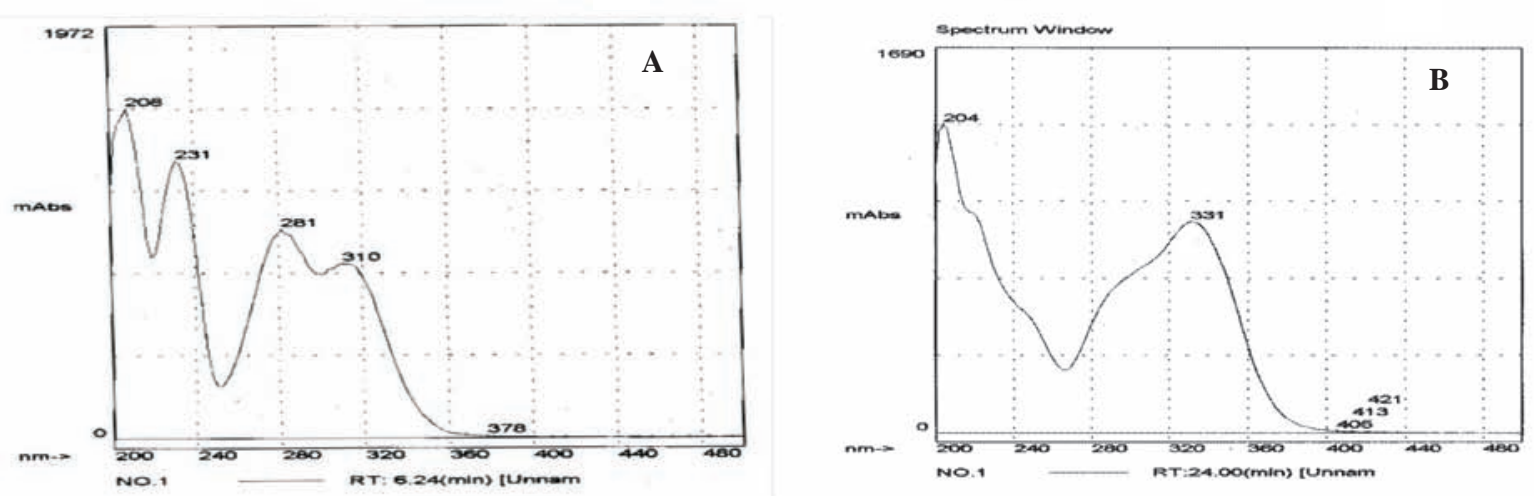

Figure 2. Ultraviolet spectrums from the compounds of retention time around 6 min (A) from the extract EA and from the compound with retention time between 23-24 min (B) in the chromatograms from the extracts EB, EA, EB and EAq of Jacaranda puberula.

Table 2. NMR ${ }^{13} \mathrm{C}\left(100 \mathrm{MHz}, \mathrm{CD}_{3} \mathrm{OD}\right)$ experimental data from verbascoside (1).

\begin{tabular}{|c|c|c|c|}
\hline Position & ${ }^{13} \mathrm{C}(\mathrm{ppm})$ & Position & ${ }^{13} \mathrm{C}(\mathrm{ppm})$ \\
\hline \multicolumn{4}{|l|}{ Aglicone } \\
\hline 1 & $131.40^{*}$ & $\mathrm{C}=\mathrm{O}$ & 168.31 \\
\hline 2 & 117.11 & Glucose & \\
\hline 3 & 144.57 & $1 ”$ & 104.11 \\
\hline 4 & 146.03 & $2 ”$ & 76.13 \\
\hline 5 & 116.30 & $3 "$ & 81.64 \\
\hline 6 & 121.27 & $4 ”$ & 70.36 \\
\hline$\alpha$ & 72.20 & $5 ”$ & 75.91 \\
\hline$\beta$ & 36.48 & 6" & 62.27 \\
\hline Caffeoyl moiety & & Rhamnose & \\
\hline $1^{\prime}$ & 127.61 & $1, "$ & 102.96 \\
\hline $2^{\prime}$ & 115.24 & $2 ”$, & 72.28 \\
\hline 3 ' & 149.70 & $3 " \prime$ & 71.99 \\
\hline $4^{\prime}$ & 146.74 & $4, "$ & 73.74 \\
\hline $5^{\prime}$ & 116.51 & $5, ”$ & 70.52 \\
\hline $6^{\prime}$ & 123.21 & $6 ”$, & 18.41 \\
\hline$\alpha ’$ & 114.64 & & \\
\hline$\beta^{6}$ & 148.01 & & \\
\hline
\end{tabular}

*Signals overlapping

Another contribution to the antioxidant activity can be related to the presence of the compound with retention time of $6.24 \mathrm{~min}$. in the EA extract (Figure 1B), also present in the EB extract (Figure 1C); in which the UV spectra (Figure 2A) which presented maximum absorptions in 206, 281 and $310 \mathrm{~nm}$ that indicate the presence of a caffeic acid group (Silverstein et al., 1994).

The experimental results from the NMR analysis (Table 3), and comparison with literature data of transcaffeic acid (Gafner et al., 1997), trans-coniferyl aldehyde (Steeves et al., 2001) and for aldehydes in general (Silverstein et al., 1994), pointed to the 3,4-di-hydroxy cis-cinnamic aldehyde (cis-caffeoyl aldehyde) (2).
The obtained data from this experiment are similar to the literature data for molecules in which the antioxidant activity is related to the presence of ortho-di hydroxyl groups in its structures (Mensor et al., 2001; Coffi et al., 2002).

The DPPH assay showed that the extracts and fractions of the Jacaranda puberula exhibited antioxidant activity. If the blood depurative property of the plant is related to the presence of antioxidant compounds in tea, which eliminate free radicals from blood, or protect biological molecules of being oxidized, J. puberula can be considered a good antioxidant phytomedicine. 
<smiles>O=C/C=C\c1ccc(O)c(O)c1</smiles>

Table 3. NMR $\mathrm{C}^{13}(100 \mathrm{MHz})$ and $\mathrm{H}^{1}(400 \mathrm{MHz})$ experimental data from cis-caffeoyl aldehyde (2) in DMSO- $\mathrm{d}_{6}$.

\begin{tabular}{cccc}
\hline Position & ${ }^{13} \mathrm{C}(\mathrm{ppm})$ & ${ }^{1} \mathrm{H}(\mathrm{ppm})$ & $J \mathrm{~Hz}$ \\
\hline 1 & 129.27 & - & - \\
2 & 115.59 & 7.23 & $d, 1.9$ \\
3 & 152.73 & - & - \\
4 & 146.40 & - & - \\
5 & 115.91 & 6.9 & $d, 8.0$ \\
6 & 124.91 & 7.27 & $d d, 8.0,1.9$ \\
$\alpha$ & 114.84 & 6.69 & $d, 8.0$ \\
$\beta$ & 130.68 & 7.04 & $d, 8.0$ \\
$\mathrm{CHO}$ & 191.38 & 9.7 & $s$ \\
\hline
\end{tabular}

Many oxidant species present in the human organism, as the oxygen reactive species ORS and the nitrogen reactive species NRS, participate of several metabolic reactions that the organism need to do. However, when excess of them are generated by inflammatory process or by diets some biological dysfunction can cause serious damages to the organism (Loureiro et al., 2002; Barreiros et al., 2006). The effects can be hyper oxidation of lipids from the membrane and the aggression to the proteins from the tissue, to the enzymes, carbohydrates and DNA. These damages are related to diseases as arthritis, heart illness, hemorrhagic shocks, cognitive dysfunctions, cancer, AIDS, and it can be the cause or the factor of the general clinic problem.

One of the worst radical species for the organism is the hydroxyl radical, $\mathrm{OH}$, because it attacks biological molecules by taking away hydrogen from them or being added to unsaturated compounds. One possible example of the hydroxyl radical attack is the action of it on the lipids from the membrane. The oxidation of lipids destabilizes the active and passive transport from the membrane, or causes the rupture of the membrane, causing the cellular death. The oxidation of lipids in the blood attack the veins walls and the arteries, becoming easy the accumulation of the lipids, causing arteriosclerosis, as possible cause of thromboses, heart attack and stroke. By this way, it is necessary to protect the human organism from the excess of ORS and NRS, through enzymes or micro molecules from our own organism or acquired through diets processes.
Diet can become the source of antioxidants compounds as the $\mathrm{C}, \mathrm{E}$ and $\mathrm{A}$ vitamins, carotenes, phenolic compound such as phenylpropanoids derivatives and flavonoids. The antioxidant activity from the last two compounds depend of the following factors: reactivity as donator agent of $\mathrm{H}$ and electrons, stability from the formed radical, reactivity with other antioxidants, capacity of coordinate transition metals, solubility and interaction with membranes in general (Barreiros et al, 2006).

Polyphenols are able to capture $\mathrm{OH}$ radicals because phenol groups are excellent reducer agents. It has been reported that verbascoside was able to inhibit lipid peroxidation by chelating ferrous íon, and scavenge hydroxyl radical (Zhao et al., 2005).

For the quelation activity is fundamental the presence of ortho-hydroxyl derivates, as those present in polyphenols including verbascoside and cis-caffeoyl aldehyde. The phenol hydroxyl groups are quelators agents due to the acid characteristic of them. The presence of hydroxyl groups in ortho position and conjugated to double-bond system allows the charge delocalization by electron donation. Finally, it is fundamental the interaction of these molecules with biomembranes. If they are enough lipophilic, it can be incorporated to the membranes that are target of ORS and NRS. If they were very polar, they can be stored into the vesicles and can kept for a long time in the organism.

Considering excessive production of free radicals in the organism as having a potential harmful effect, 
antioxidants plants or phytomedicines could be seen as cleaning agents, acting through several antioxidant mechanisms, in the promotion of health. By this way, the concept of blood depuration focused on the antioxidant activity of Jacaranda puberula, was confirmed by the experimental results showed, having the popular use of it as reference, once seen that the leaf tea can concentrate a high amount of phenol compounds.

\section{ACKNOWLEDGEMENTS}

We thank CNPq for the schorlarship for P.M.L.S. We are grateful to Prof. Dr. Ivo José Cursino (Universidade Estadual do Norte Fluminense) for support.

\section{REFERENCES}

Barreiros ALBS, David JM, David JP 2006. Estresse oxidativo: relação entre geração de espécies reativas e defesa do organismo. Quim Nova 29: 113-123.

Castro O, Umaña E, Herrera ML 1990. Biological and chemical potential of Verbena littoralis, a medical plant used in Costa Rica as na antidiarrhea agent. Quim Nova 13: 310311.

Cioffi G, D'auria M, Braça A, Mendez J, Castillo A, Morelli I, De Simone F, De Tommasi N 2002. Antioxidant and free-radical scavenging activity of constuents of leaves of Tachigalia paniculata. J Nat Prod 65: 1526-1529.

Corrêa MP 1975. Diccionário das plantas úteis do Brasil. Rio de Janeiro: Ministério da Agricultura/Instituto Brasileiro de Desenvolvimento Florestal.

Didry N, Seidel V, Dubreil L, Tillequin F, Bailleul F 1999. Isolation and antibacterial activity of phenylpropanoid derivatives from Ballota nigra. J Ethnopharmacol 67: 197-202.

Gafner S, Wolfender JL, Niaga M, Hostettmann K 1997. Phenylpropanoid glycosides from Newbouldia laevis roots. Phytochemistry 44: 687-690.

Kanchanapoom T, Kasai R, Yamasaki K 2002. Phenolic glycosides from Markhamia stipulate. Phytochemistry 59: 557-563.

Lorenzi H 2002. Árvores brasileiras: manual de identificação e cultivo de plantas nativas do Brasil. São Paulo: Plantarum.

Loureiro AP, Di Mascio P, Medeiros MHG 2002. Formação de adutos exocíclicos com bases de DNA: implicações em mutagênese e carcinogênese. Quim Nova 25: 777-793.

Martins MBG, Castro AA, Cavalheiro AJ 2008. Caracterização anatômica e química de folhas de Jacaranda puberula (Bignoniaceae) presente na Mata Atlântica. Rev Bras Farmacogn 18: 600-607.

Mensor LL, Menezes FS, Leitão GG, Reis AS, Santos TC, Coube CS, Leitão SG 2001. Screening of Brazilian plant extracts for antioxidant activity by use of DPPH free radical method. Phytother Res 15: 127-130.

Silverstein RM, Bassler GC, Morril TC 1994. Identificação espectrométrica de compostos orgânicos. Rio de Janeiro: Guanabara Koogan.

Steeves V, Förster H, Pommer U, Savidge R 2001. Coniferyl alcohol metabolism in conifers-I. Glucosidic turnover of cinnamyl aldehydes by UDPG: coniferyl alcohol glucosyltransferase from pine cambium. Phytochemistry 57: 1085-1093.

Valko M, Leibfritz D, Moncol J, Cronin MTD, Mazur M, Telser J 2007. Free radicals and antioxidants in normal physiological functions and human disease. Int J Biochem Cell B 39: 44-48.

Williams WB, Cuvelier ME, Berse C 1995. Use a free radical method to evaluate antioxidant activity. Lebensm Wiss Technol 28: 25-30.

Zhao C, Dodin G, Yuan C, Chen H, Zheng, R, Jin Z, Fan BT 2005. "In vitro" protection of DNA from Fenton reaction by plant polyphenol verbascoside. Biochim Biophys Acta 1723: 114-123. 